\title{
Raising Expectations for U.S. Youth with Disabilities: Federal Disability Policy Advances Integrated Employment
}

JEANNE NOVAK $^{1}$

$\propto$ While conversations around the inclusion of individuals with disabilities often focus on the educational rights and needs of children with disabilities during their school years, there is a growing recognition that the period of transition from secondary school to adult roles is a critical time in the lives of individuals with disabilities. For young people, gaining meaningful employment in a typical community job is an important step towards realising full community membership. The present article examines how contemporary U.S. federal disability policy has heightened expectations that youth with disabilities - including those with significant disabilities can and should be prepared to work in integrated workplaces. The article begins with a consideration of how evolving assumptions about the nature of disability and the employment potential of individuals with significant disabilities have influenced the development of federal disability policy in the U.S. This is followed by an overview of key legislative and policy developments in the areas of civil rights and workforce development that have the potential to dramatically impact the employment outlook for young people with disabilities. The article concludes with a discussion of challenges in translating the legislative intent of federal disability policy into noticeable improvements in employment outcomes, along with recommendations for aligning legislation, funding priorities and service delivery systems to achieve policy goals.

Keywords: equal opportunity, integrated employment, presumption of employability, secondary transition, social model of disability 


\title{
Dviganje pričakovanj za mlade iz Združenih držav Amerike s posebnimi potrebami: zvezna politika na področju posebnih potreb napreduje pri integriranem zaposlovanju
}

\author{
JEANNE NovAK
}

$\approx$ Medtem ko se diskusije o inkluziji posameznikov s posebnimi potrebami pogosto osredinjajo na pravice do izobraževanja in potrebe otrok s posebnimi potrebami med šolanjem, se veča tudi prepoznavanje dejstva, da je tudi obdobje prehoda iz srednje šole $\mathrm{v}$ odraslost kritično obdobje v življenju posameznikov s posebnimi potrebami. Za mlade ljudi je pridobivanje zaposlitve $\mathrm{v}$ skupnosti pomemben korak $\mathrm{k}$ temu, da postanejo polnopravni člani skupnosti. V prispevku je predstavljeno, kako je trenutna zvezna politika v Združenih državah Amerike (ZDA) na področju posebnih potreb zvišala pričakovanja glede tega, da mladi s posebnimi potrebami, vključno s tistimi s precejšnjimi primanjkljaji, so in morajo biti pripravljeni za delo na integriranih delovnih mestih. Avtorji na začetku predstavijo, kako so spremembe na področju poznavanja narave posebnih potreb in zaposlitvenega potenciala oseb $s$ precejšnjimi primanjkljaji vplivale na razvoj zvezne politike na področju posebnih potreb v ZDA. Sledi pregled ključnih pravnih in zakonodajnih sprememb na področjih državljanskih pravic in razvoja delovne sile, ki lahko dramatično vplivajo na zaposlovanje mladih s posebnimi potrebami. Na koncu so predstavljeni izzivi, kako zakonodajne namene prenesti $\mathrm{v}$ vidne izboljšave rezultatov zaposlovanja, s priporočili za usklajevanje zakonodaje, prioritetami financiranja in s podpornimi sistemi, ki bodo omogočili doseganje ciljev.

Ključne besede: enake možnosti, integrirana zaposlitev, zaposlitvene domneve, sekundarni prehod, socialni model posebnih potreb 
Conversations around the inclusion of individuals with disabilities often focus on the educational rights and needs of children with disabilities during their school years (Curcic, 2009; Shogren \& Wehmeyer, 2014; Smyth et al., 2014); however, increased policy and research attention in the United States and in other countries is being directed toward the transition of youth with disabilities from school to adult roles in their communities (Ebersold, 2012; Wagner, Newman, Cameto, Levine, \& Garza, 2006; Wehman, 2012). The shift from adolescence to adulthood is a significant life transition for all young people, and is often met with some degree of uncertainty about the future. For youth with significant disabilities and their families, the future may be especially uncertain: Will they have opportunities to choose where, with whom, and how they want to live? Will they be able pursue higher education or become gainfully employed? Or, conversely, will they be limited to live, work and recreate within segregated service settings based solely on their disability status? These questions speak to the heart of what it means to be included in one's community.

For young people with intellectual disabilities, mental illness and other significant disabilities, securing employment in the open labour market is an important step towards realising full community membership. In addition to offering benefits in terms of monetary gain, personal meaning and quality of life (Dunn, Wewiorski, \& Rogers, 2008; Kober \& Eggleton, 2005), integrated employment provides avenues for assuming valued social roles (Lemay, 2006) and for developing a host of relationships at work and in the community (Brown, Shiraga, \& Kessler, 2006). Preparing youth with disabilities to enter this competitive labour force has been a dominant theme of secondary education and transition efforts in the U.S. for the past several decades (Wehmeyer \& Webb, 2012).

The purpose of the present article is to examine how contemporary U.S. disability policy has heightened expectations for young people with disabilities - including those with significant disabilities - to achieve meaningful employment in their communities. First, I delineate core assumptions and values that underpin current federal legislation and policy regarding the employment of people with disabilities. Next, I review specific statutes that have significantly pushed the integrated employment agenda in the U.S. in recent decades. I conclude by highlighting good practices for aligning service delivery systems to achieve employment outcomes for people with significant disabilities that fulfil the promise of the country's disability policy. 


\section{Goals, Assumptions and Principles Guiding U.S. Dis- ability Employment Policy}

Disability is a natural part of human experience and in no way diminishes the right of individuals to live independently; enjoy self-determination; make choices; contribute to society; pursue meaningful careers; and enjoy full inclusion and integration in the economic, political, social, cultural, and educational mainstream of American society. [Rehabilitation Act, 29 U.S.C. $\$ 701(a)(3)]$

This passage, excerpted from the Rehabilitation Act of 1973, as amended, illustrates a fundamental precept that has guided the development of U.S. disability policy for the past four decades. The understanding of disability as a natural and normal part of life that should not limit one's right to participate fully in society is reinforced by four overarching public policy goals with regard to people with disabilities (Silverstein, 2000). These goals, articulated in the Americans with Disabilities Act (ADA) of 1990, are "to assure equality of opportunity, full participation, independent living, and economic self-sufficiency for such individuals" [ADA, 42 U.S.C. $\$ 12101(\mathrm{a})(7)$ ]. The current paradigm of disability policy is a departure from an earlier paradigm that resulted in the exclusion and segregation of people with disabilities and the denial of appropriate and necessary services (Silverstein, 2010). Policymakers' rejection of the old paradigm in favour of the current paradigm reflects a change in underlying assumptions about the nature of disability, the origin of problems faced by those who have disabilities, and their capacity to become meaningfully employed.

\section{Changing Conceptualisations of Disability}

Throughout much of history, disability has been understood predominantly in medical terms: as a sickness or disease subject to prevention, cure or amelioration. This medical model of disability views physical or mental impairments as medical conditions that limit the functional capacities of individuals with disabilities. The model assumes that the primary problem faced by people with disabilities lies in their incapacity to contribute in the workplace in a meaningful way, or to otherwise participate in society (Scotch, 2000). Because the medical model locates the "problem" within the individual, people with disabilities have historically been separated from society and subjected to medical treatment or intervention focused on "fixing" them.

In the latter part of the $20^{\text {th }}$ century, a fundamental shift occurred in 
the conceptualisation of disability in direct response to the pervasive influence of the medical model. This shift began with the emergence of the social model of disability in the United Kingdom, which describes disability not in terms of physical or mental impairment, but as a social construct shaped by social, cultural, political and environmental factors (Oliver, 1996). This model regards limitations faced by people with disabilities as resulting from society's failure to adequately ameliorate the attitudinal and institutional barriers that preclude their full participation in society (Scotch, 2000). Subsequent conceptualisations have criticised the adequacy of either model on its own to explain the complex phenomenon of disability, instead asserting that the interaction between characteristics of the person and characteristics of the overall context in which the person lives more adequately explains the nature of disability (e.g., World Health Organization, 2001).

\section{Presumption of Employability}

There have long been debates about whether people with significant disabilities are capable of working in integrated environments (Black, 1992; Wehman \& Moon, 1987). The U.S. has a protracted history of segregating and sheltering workers with disabilities (National Disability Rights Network, 2011). Dating back to the opening of the first sheltered workshop in 1840, through the period of rapid expansion of sheltered workshops in the 1950s and 196os, the stated purpose of segregated work programmes has been to meet the needs of people incapable of working in the regular workforce due to the severity of their physical, intellectual or mental impairments. Workshops were viewed as protective environments "sheltered" from public ridicule, judgment and shame, where people could develop the job skills necessary to compete for traditional community jobs (Black, 1992).

A principal assumption at the time was that people with intellectual and developmental disabilities needed to move through a continuum of rehabilitation services to prepare to work in a regular job in the community (Bellamy, Rhodes, Mank, \& Albin, 1988; Taylor, 1988). Moving through the traditional continuum of rehabilitation services meant that an individual first participated in prevocational education, then a work-activity centre, then sheltered employment, before finally being placed in a community job. A flaw in the implementation of this readiness model was that few people were ever determined ready for community employment and the vast majority remained confined to segregated settings in perpetuity.

The rehabilitation trajectory for people with serious mental illness likewise fell short of employment in the community. Guided by the prevailing 
medical model of the day, rehabilitation efforts prioritised "curing" their disease or "fixing" their disorder. Only after achieving and maintaining mental well-being were they considered ready for work (Ford, 1995). It soon became apparent that adhering to a readiness model of employment resulted in little more than endlessly preparing people for jobs that never materialised.

By the early 1980s, the axiom "special people need special places" was being challenged by reports of individuals with significant disabilities living and working successfully in the community (Mank, 1994). The notion that people with significant disabilities needed to work in separate facilities apart from workers without disabilities, where their unique needs could be met by specially trained professionals, continued to erode as advances in supported employment opened the door to community employment for many people once considered unemployable. During the past three decades, a growing body of empirical evidence from the fields of psychiatric rehabilitation and developmental disabilities has demonstrated the effectiveness of supported employment in assisting individuals achieve employment in the open labour market, while day treatment, prevocational training and sheltered employment have been shown to be relatively ineffective in preparing individuals for competitive employment (e.g., Bond, 2004; Cimera, Wehman, West, \& Burgess, 2012; Marshall et al., 2014). Supported employment involves systematic job development based on an individual's unique strengths, interests and needs, followed by ongoing support to ensure the individual's long-term success on the job. Support may include activities such as providing on-the-job training, implementing workplace accommodations, and consulting with on-site supervisors and coworkers to encourage their training and support of the individual.

Research evidence discrediting the vocational readiness model, along with success stories of individuals even with the most significant disabilities working in their communities, has led advocates to call for an end to sheltered employment and a presumption of employability for all. In a 2011 report entitled "Segregated and exploited: The failure of the disability service system to provide quality work", the National Disability Rights Network (NDRN) sought, in part, to dispel myths about the capabilities of people with disabilities to be fully employed, integral members of the U.S. workforce. The report asserts that "Workers with disabilities can be employed and be paid equally with the appropriate job development, training, work support, and assistive technology" (p. 34). It calls for an end not only to sheltered employment but also to an antiquated labour law exception that allows workshops and other employers to pay less than minimum wages to workers with disabilities whose productive capacity is impaired by a physical or mental disability. A separate group of 25 national 
disability rights organisations, including state directors of developmental disabilities and mental health agencies, issued a statement of key principles for community integration that made a similar declaration of the vocational potential of individuals with disabilities:

Individuals with disabilities should have the opportunity to be employed in non-segregated, regular workplaces. Virtually all individuals with disabilities can be employed and earn the same wages as people without disabilities. When needed for such employment, they should have access to supported or customized employment. They should be afforded options other than sheltered work, day treatment, clubhouses, and other segregated programs. (U.S. Senate, 2013, p. 14)

These statements by disability rights organisations underscore the presumption that individuals with significant disabilities are employable, and they are reflected in the common refrain of self-advocates: Give us real jobs, for real money, in real businesses in the community!

Taken together, evolving assumptions about the nature of disability and the employment potential of people with significant disabilities have had a significant impact on the development of federal disability policy in the U.S. in recent years. This impact is evident in current civil rights statutes mandating equal opportunity in employment, as well as in other federal legislation and regulations advancing integrated employment as the optimal employment outcome for all persons with disabilities.

\section{Key Federal Legislative and Policy Developments Ad- vancing Integrated Employment}

\section{Equal Employment Opportunity is the Law}

The Americans with Disabilities Act of 1990 is considered a landmark civil rights statute in the U.S. The ADA prohibits discrimination and ensures equal opportunity for persons with disabilities in employment, state and local government services, public accommodations, commercial facilities and transportation. Both the ADA and its predecessor, Section 504 of the Rehabilitation Act of 1973, contain strong anti-discrimination language related to employment. While the Rehabilitation Act prohibits employment discrimination in federally funded programmes and activities, the ADA extends protections against employment discrimination to the private sector. Specifically, Title I of the ADA requires employers with 15 or more employees to provide qualified individuals 
with disabilities the opportunity to benefit from the full range of employmentrelated opportunities available to others. The law prohibits discrimination in all employment practices, including recruitment, hiring, termination, promotion, compensation, job training and other privileges of employment. Moreover, it prohibits employers from asking an applicant disability-related questions prior to making a conditional job offer.

Title I of the ADA requires employers to make reasonable accommodations for qualified job applicants and employees with disabilities. Under the law, reasonable accommodations are any modifications or adjustments that enable the individual to participate in the application process, perform the essential job functions, or enjoy equal access to benefits available to individuals without disabilities in the workplace. Essential functions of a job are the fundamental duties required of the position. Accommodations may range from making a work area physically accessible and providing training materials in an accessible format to modifying work schedules or granting time off for an employee to receive treatment for a disability. An employer is only required to accommodate a qualified individual with a disability. A qualified individual is one who can perform the essential functions of a job with or without a reasonable accommodation. Employers are not required to lower quality or quantity standards as an accommodation. In addition, an employer is not required to provide any accommodation that would impose an undue hardship (i.e., significant difficulty or expense) on the operation of the employer's business.

Although Title I of the ADA prohibits employment discrimination on the basis of disability, it is not an affirmative action statute and it does not establish a quota system. Private businesses in the U.S. do not have a duty to hire people with disabilities, and people with disabilities are not entitled to employment. Rather, employers are free to make all employment decisions, including selecting the most qualified applicant for a job and terminating an individual's employment, as long as these decisions are based on reasons unrelated to a disability and as long as the results of the employer's actions do not systematically disadvantage individuals with disabilities as a protected group (Reskin, 2001).

Passage of the ADA in 1990 has been described as "a watershed moment for disability advocates attempting to frame disability not as purely a medical condition, but rather as a civil rights issue to be considered under the umbrella of antidiscrimination rights" (Schlesinger, 2014, p. 2120). It represented a significant shift in federal public policy, reflecting a rejection of the medical model of disability in favour of a new paradigm that views disability as resulting from the interaction between a person's impairment and the environmental and attitudinal barriers that restrict his or her participation in society (Scotch, 2000). 
This shift is consistent with an international trend in adopting a social model of disability in policy development, exemplified by the introduction of the United Nations (UN) Convention on the Rights of Persons with Disabilities in 2006 and its subsequent ratification by 151 nations as of December 2014 (United Nations Enable, 2012).

\section{The ADA Integration Mandate}

The Americans with Disabilities Act has been interpreted as more than an anti-discrimination statute; it has been heralded as a federal policy commitment to the social inclusion of people with disabilities (Scotch, 2000). In passing the ADA, the U.S. Legislature described discrimination against people with disabilities through isolation and segregation as a serious and pervasive national problem. Title II of the ADA prohibits discrimination against individuals with disabilities in the services provided by state and local governments. Furthermore, the 1991 regulations implementing Title II require public entities to "administer services, programs, and activities in the most integrated setting appropriate to the needs of qualified individuals with disabilities" [ 28 C.F.R. $\$$ $35.130(\mathrm{~d})$ ]. The most integrated setting means a setting that "enables individuals with disabilities to interact with non-disabled persons to the fullest extent possible" [28 C.F.R. Pt. 35 App. A]. The regulatory requirement that public services be provided in the most integrated setting appropriate to each person's needs is known as the law's integration mandate.

The U.S. Supreme Court's decision in Olmstead v. L.C. (1999) significantly shaped interpretation of the ADA's integration mandate (Hoffman, 2013). The Olmstead case involved two women with mental illness and intellectual disabilities who lived in a state-run institution. Despite determination by their treatment teams that the women could be appropriately served in the community, they remained in the institution for several years. The women sued, claiming that being confined in the institution was a violation of their rights under Title II of the ADA. In 1999, the Supreme Court upheld the right of the women to move from the institution into the community, citing that such segregation "perpetuates unwarranted assumptions that persons so isolated are incapable or unworthy of participating in community life" (527 U.S. 600). The Olmstead decision made explicit the responsibility of states to provide services for people with disabilities in the most integrated environment appropriate.

In 2009, the federal government launched a Community Living Initiative to promote federal partnerships that advance the directive of the Olmstead decision (U.S. Senate, 2013). The initiative is supported by recent changes to 
Medicaid, the nation's largest funding source for long-term support services for people with disabilities. Changes to federal Medicaid rules in 2014 have created new financial incentives for states to rebalance their long-term support service systems away from reliance on institutional facilities and towards home and community-based settings (U.S. Department of Health and Human Services, 2014). In addition, the U.S. Department of Justice (DOJ) has stepped up its enforcement of the ADA's integration mandate as articulated in Olmstead in a wide variety of residential and non-residential settings (DOJ, 2011). Sheltered workshops and facility-based day programmes in several states and communities have been found to unnecessarily segregate people with disabilities in violation of the ADA (e.g., Rinaldi, 2014). Placement in such settings has been deemed to be a form of institutionalisation that prevents people with disabilities from becoming fully included in their communities. Subsequently, in 2014, the United States entered into the nation's first state-wide settlement affirming the right of people with disabilities to receive employment and day activity services in community settings (DOJ, 2014). A DOJ investigation of Rhode Island's system of service delivery for persons with intellectual and developmental disabilities found that thousands of individuals spend the majority of their daytime hours receiving services in segregated settings, even though they are interested in and capable of receiving integrated employment and day services in the community. The State's heavy reliance on sheltered workshops and facility-based day programmes to the exclusion of integrated alternatives was found to violate the intent and purpose of the ADA. In an unprecedented 10-year agreement, Rhode Island has agreed to provide (a) individualised supported employment placements in typical community jobs for approximately 2,00o transition-age youth and adults, and (b) career preparation experiences, such as internships, jobsite visits and career mentoring, for youth, thus preparing them for integrated employment at competitive wages.

The integration mandate of the ADA - along with subsequent laws, regulations and legal decisions - sends an unambiguous message about the rights of individuals with disabilities to live integrated lives and pursue meaningful careers in the community. The next section describes the evolution of federal vocational rehabilitation legislation and employment policy that has led to the recognition of competitive integrated employment as the optimal employment outcome for youth and adults with disabilities. 


\section{Competitive Integrated Employment as the Optimal Employment Outcome}

The evolution of vocational rehabilitation legislation and policy in the U.S. over the past several decades has been influenced by changing assumptions about the nature of disability and the employment potential of people with significant disabilities. The first civilian vocational rehabilitation (VR) programme in the U.S. was established in 1920 (Rubin \& Roessler, 2007). At that time, services were limited to individuals with physical disabilities who could be expected to become gainfully employed after receiving time-limited vocational training services. People with significant physical and mental disabilities would have to wait until the U.S. Legislature enacted the Rehabilitation Act of 1973 before they would become the priority recipients of VR services and could no longer be denied participation in the programme due to the cost or complexity of their service needs (Bellini, 1998). The Rehabilitation Act Amendments of 1986 shared a focus on providing services to job seekers with significant disabilities and established a dedicated supported employment programme to assist people with the most significant disabilities, who require intensive, ongoing support in order to achieve and retain competitive employment. The 1992 Amendments codified the presumption that all individuals can benefit from VR services when provided with appropriate services and supports. No longer could individuals with significant disabilities be denied services simply because they were presumed to have limited "rehabilitation potential" (West, 1996). Today, the onus is on state VR agencies to present clear and convincing evidence to rebut the presumption of benefit. In addition, since 2001, VR funds can no longer be used for the long-term placement of people with disabilities in sheltered workshops and other segregated settings [34 C.F.R. \$ $361.5(b)(16)]$.

The most recent amendments to the Rehabilitation Act - now part of the broader Workforce Innovation and Opportunity Act of 2014 (WIOA) - can be expected to push to the integrated employment agenda for youth transitioning from school to work. For the first time, competitive integrated employment is identified as the optimal employment outcome of VR services (Hoff, 2014). Competitive integrated employment refers to jobs held by people with disabilities in workplaces in which the majority of employees do not have disabilities. In these jobs, employees with disabilities are paid directly by their employers and earn wages consistent with those paid to employees without disabilities performing the same or similar work. It is worth noting that the WIOA was enacted against the backdrop of a proliferation of state Employment First initiatives over the past decade (Kiernan, Hoff, Freeze, \& Mank, 2011). Employment 
First initiatives reflect a commitment by states to align their policies, funding and service delivery systems to promote typical community employment as the first choice and preferred outcome for youth and adults with significant disabilities (Martinez, 2013). Although the term Employment First is not specifically mentioned in the WIOA, the influence of the Employment First movement on its development is evident.

Furthermore, new provisions in the law require VR agencies to assume a greater role in preparing youth with disabilities for competitive integrated employment. The statute includes specific provisions to (a) increase the involvement of VR agencies in providing pre-employment transition coordination and services such as work-based learning experiences; (b) increase supported employment services for young adults; (c) require formal cooperative agreements between state VR, Medicaid and developmental disabilities agencies with respect to the delivery of vocational rehabilitation services; (d) limit the entry of young adults with disabilities into jobs that pay less than the minimum wage; and (e) prohibit schools from contracting with sub-minimum wage providers, such as sheltered workshops, to provide transition services.

In a blog post announcing appointments to the newly-created Department of Labor (DOL) Advisory Committee on Increasing Competitive Integrated Employment for Individuals with Disabilities, DOL Secretary Tom Perez (2015) succinctly stated why the Act identifies competitive integrated employment as the optimal employment outcome for youth and adults with disabilities:

Competitive integrated employment works - for individuals, for employers and for society. Models have shown repeatedly that people previously considered "unemployable" can work, can be productive and can achieve independence. As such, investing in this approach is a wise use of public funds (paragraph 5).

The WIOA has the potential to dramatically impact the employment outlook for young people with significant disabilities. Consistent and widespread implementation of models and good practices for assisting young people to prepare for and enter integrated employment will be essential to the realisation of this potential. 


\section{Aligning Policy, Funding and Service Delivery to Achieve Integrated Employment Outcomes}

More than any generation before them, today's youth with significant disabilities have benefitted from the civil rights protections designed to enable them to lead integrated adult lives. The legislative and policy developments discussed have raised the employment expectations of these youth; yet, for many, the promise of a real job for real money remains elusive (NDRN, 2011, 2012). Americans with disabilities experience higher unemployment rates, lower earnings and higher poverty rates than Americans without disabilities (Brault, 2014; NCD, 2014). The 2014 Disability Statistics Annual Report estimates that 33.9\% of working-age adults with disabilities are employed, compared with $74.2 \%$ of people without disabilities (Stoddard, 2014). Those whose disabilities are significant experience even greater employment and economic disparities. For example, only one in five individuals receiving day supports from state intellectual and developmental disabilities (IDD) agencies in 2012 participated in integrated employment services (Butterworth et al., 2014). It is clear from these statistics that translating the legislative intent of federal disability policy into noticeable improvements in employment outcomes will require the alignment of legislation, funding priorities and service delivery systems in order to achieve policy goals.

\section{Develop a Consistent National Policy Framework Supporting Integrated Employment}

The legislative intent of contemporary disability policy is to ensure equality of opportunity, full participation, independent living and economic self-sufficiency for people with disabilities. This has not always been the case. Legislation enacted prior to the 1960 s was heavily influenced by society's charity approach to meeting the needs of "the disabled", along with a general acceptance of the medical model with its focus on deficits within the person (NCD, 2014). Disability rights advocates have targeted laws enacted during this time period that conflict with current national disability policy promoting the full workplace integration of people with disabilities. One such provision is the labour law exception allowing employers to pay some people with significant disabilities a subminimum wage. When this law was enacted in 1938, it was a viewed as a cutting-edge way to provide Americans with disabilities the opportunity to perform work activity in a protective workshop setting. However, we live in a new time, with new technology innovations and service delivery models, and new expectations. The payment of federally sanctioned subminimum 
wages to workers with disabilities is viewed today as an outdated, paternalistic approach that perpetuates the perception that individuals with disabilities are incapable or undeserving of earning commensurate wages; it also limits workers' potential for independence and economic self-sufficiency (NDRN, 2011). For these reasons, the National Council on Disabilities (NCD, 2014) - the independent federal agency charged with advising the U.S. President and Legislature on disability matters - has joined disability rights advocacy organisations in calling for an end to the subminimum wage.

The NCD (2014) also recommends that the Individuals with Disabilities Education Act (IDEA) be amended to improve its alignment with the ADA and the WIOA. The IDEA, the federal law that outlines the educational rights of children with disabilities, requires schools to develop an individualised transition plan for students with disabilities aged 16 and older. The plan specifies the student's post-school goal for employment, as well as the transition services that will be provided to assist the student in achieving that goal. Although the IDEA requires systematic planning and services related to students' employment goals, it does not recognise competitive integrated employment as the preferred outcome of the transition process. The NCD recommends that schools be prohibited from identifying placement in a subminimum wage programme as an acceptable post-school transition goal or service on the transition plan.

\section{Redirect State Service Delivery and Funding from Segregated to Integrated Employment Options}

The United States, like many countries, is struggling to realise a primary principle of disability policy: the right of people with disabilities to earn a living through employment in inclusive, accessible workplaces in the open labour market (Hoffman, 2013; United Nations, 2006). The U.S. has a federalist legal system with both federal and state constitutions, statutes and common laws that impact the rights of people with disabilities. More than two decades after passage of the Americans with Disabilities Act, many states continue to spend less on services provided in integrated settings than services provided in segregated settings (Butterworth et al., 2014; U.S. Senate, 2013). On average, state IDD agencies spend less than $\$ 1$ on integrated employment services for every $\$ 4$ utilised for facility-based programmes. However, an increasing number of states have taken concrete steps in recent years to correct this imbalance by redirecting funding from segregated to integrated employment service options.

Much of the work by states to align their policies and funding in support of integrated employment outcomes is being carried out under the aegis 
of Employment First. At least 34 of the 50 states have Employment First initiatives targeting employment in typical work settings as the funding priority and primary outcome for individuals with significant disabilities (Butterworth et al., 2014). Common state-level reform efforts aim to (a) increase the access of students with disabilities to inclusive educational settings and communitybased work experiences in order to inform their choices regarding post-school service options; (b) adjust rate setting and reimbursement methodologies within the state's employment and day service system to incentivise providers to deliver services in integrated settings; (c) provide training and technical assistance to increase the capacity of service providers and the general community to implement supported employment practices; and (d) provide counselling to individuals and families about the impact of work on the receipt of government benefits, highlighting incentives within the law that enable people to work without risking the loss of these benefits (Butterworth et al., 2014; NCD, 2012; NDRN, 2012). The State of Vermont closed its final sheltered workshop in 2003, and today has an integrated employment rate for people with developmental disabilities that is twice the national average. A Vermont policymaker explained the impetus for change in this way: "We made the decision many years ago to invest our money where our values were and not fund the outcomes we didn't believe in. That has made all the difference" (as cited in NCD, 2012, p. 12).

\section{Implement Additional Equality Measures to Encourage Integrated Employment}

Some disability policy scholars have argued that the strong antidiscrimination legislation enacted in the U.S. is, by itself, insufficient to ensure equal opportunity in employment for people with disabilities. Stein and Stein (2007) maintain that "Civil rights are directed at ensuring equal treatment but not equal opportunity. As a result, the $\mathrm{ADA}$ and similarly formulated statutes are not adequately empowered to bring about disabled citizens' full social inclusion" (p. 1209). In 2008, the National Council on Disability analysed gaps in current U.S. disability vis-à-vis the UN Convention on the Rights of Persons with Disabilities (CRPD). According to the report,

Employment-related antidiscrimination prohibitions are only effective when linked with equality measures that alter workplace hierarchies and cultures. These latter type programs are typical of international approaches to disability law and policy, especially within the CRPD, but excluded by the U.S. perspective of civil rights. (p. 24) 
Examples of equality measures directed towards people with disabilities or employers include quota systems, affirmative action, vocational training, trial employment, tax subsidies for extra-reasonable accommodations, and preferential contracts (NCD, 2008; Stein \& Stein, 2007).

In light of the chronic disproportionately high rate of unemployment among Americans with disabilities, the U.S. Federal Government has launched a number of initiatives to establish itself as a model employer of people of disabilities (NCD, 2014). Among these are a 2010 executive order for the Government to develop strategies to enhance recruitment, employment and retention of people with disabilities, and a hiring authority that enables job seekers with significant disabilities to pursue appointment to federal agencies through a noncompetitive hiring process. Changes to regulatory provisions released in 2013 require federal contractors to set a $7 \%$ workforce utilisation goal for employment of individuals with disabilities. Finally, a 2014 executive order increased the minimum wage for all employees of federal contractors, including employees with significant disabilities who had previously been paid subminimum wages. These efforts demonstrate a commitment by the Federal Government to promote not only equal treatment, but also equal opportunity for Americans with disabilities. The NCD (2014) identifies additional federal actions needed in the areas of transportation, customised employment and accessible technology to maximise employment opportunities for people with disabilities.

\section{Conclusion}

While disability history, legislation, terminology and service delivery systems vary greatly from country to country, common questions remain: What will happen to youth with disabilities as they enter adulthood? Will they find employment that is both meaningful and gainful? U.S. federal disability policy has raised the expectation that youth with disabilities, including youth with significant disabilities, will achieve meaningful employment in their communities. The current disability policy framework reflects the belief that work is a highly valued activity in U.S. culture, that youth with significant disabilities can and should be prepared to work in regular businesses, and that public agencies bear a responsibility to empower youth to maximise their opportunities for integrated employment. Future efforts to align service delivery systems and funding priorities with federal policy goals will determine the extent to which reality meets these ideals. 


\title{
Acknowledgement
}

\author{
An earlier version of this paper was presented at the 5 th Days of Social \\ Economy Conference in Ljubljana, Slovenia, 23 October 2014.
}

\section{References}

Americans with Disabilities Act of 1990, 42 U.S.C. \$12101 et seq. (2009).

Americans with Disabilities Act Title II Regulations, Part 35 Nondiscrimination on the Basis of Disability in State and Local Government Services, 28 C.F.R. $\$ 35.101$ et seq. (2010).

Bellini, J. (1998). Equity and the order of selection mandate: Critical issues in implementation and evaluation. Journal of Disability Policy Studies, 9(1), 107-125.

Bellamy, G. T., Rhodes, L. E., Mank, D. M., \& Albin, J. M. (1988). Supported employment: A community implementation guide. Baltimore, MD: Paul H. Brookes.

Black, B. J. (1992). A kind word for sheltered work. Psychosocial Rehabilitation Journal, 15(4), 87-89. Bond, G. R. (2004). Supported employment: Evidence for an evidence-based practice. Psychiatric Rehabilitation Journal, 27(4), 345-359.

Brault, M. W. (2012). Americans with Disabilities: 2010. Household Economic Studies. Current Population Reports. Retrieved from U.S. Census Bureau website: http://www.census.gov/prod/2012pubs/p7o-131.pdf Brown, L., Shiraga, B., \& Kessler, K. (2006). The quest for ordinary lives: The integrated post-school vocational functioning of 50 workers with significant disabilities. Research \& Practice for Persons with Severe Disabilities, 31(2), 93-121.

Butterworth, J. Smith, F. A., Hall, A. C., Migliore, A., Winsor, J., \& Domin, D. (2014). StateData: The national report on employment services and outcomes, 2013 edition. Boston, MA: University of Massachusetts, Institute for Community Inclusion. Retrieved from http://book.statedata.info/13/ Cimera, R. E., Wehman, P., West, M., \& Burgess, S. (2012). Do sheltered workshops enhance employment outcomes for adults with autism spectrum disorder? Autism: The International Journal of Research and Practice, 16(1), 87-94.

Curcic, S. (2009). Inclusion in PK-12: An international perspective. International Journal of Inclusive Education, 13(5), 517-538.

Dunn, E. C., Wewiorski, N. J., \& Rogers, E. S. (2008). The meaning and importance of employment to people in recovery from serious mental illness: Results of a qualitative study. Psychiatric Rehabilitation Journal, 32(1), 59-62.

Ebersold, S. (2012). Transitions to tertiary education and work for youth with disabilities. Retrieved from Organisation for Economic Cooperation and Development (OECD) website: http://dx.doi. org/10.1787/9789264177895-en

Ford, L. H. (1995). Providing employment support for people with long-term mental illness: Choices, resources, and practical strategies. Baltimore, MD: Paul H. Brookes.

Hoff, D. (2014). WIA is now WIOA: What the new bill means for people with disabilities. The Institute 
Brief, 31, 1-4. Retrieved from http://www.communityinclusion.org/pdf/IB31_F.pdf

Hoffman, L. C. (2013). An employment opportunity or a discrimination dilemma? Sheltered workshops and the employment of the disabled. University of Pennsylvania Journal of Law and Social Change, 16, 151-179. Retrieved from http://scholarship.law.upenn.edu/cgi/viewcontent. cgi article $=1150 \&$ context $=$ jlasc

Kiernan, W. E., Hoff, D., Freeze, S., \& Mank, D. M. (2011). Employment First: A beginning not an end. Intellectual and Developmental Disabilities, 49(4), 300-304. doi:10.1352/1934-9556-49.4.300

Kober, R., \& Eggleton, I. R. C. (2005). The effects of different types of employment on quality of life. Journal of Intellectual Disability Research, 49, 756-760.

Lemay, R. (2006). Social role valorization insights into the social integration conundrum. Mental Retardation, 44, 1-12.

Mank, D. (1994). The underachievement of supported employment: A call for reinvestment. Journal of Disability Policy Studies, 5(2), 1-24.

Marshall, T., Goldberg, R. W. Braude, L., Dougherty, R. H., Daniels, A. S., Ghose, S. S., \& Delphin-

Rittmon, M. E. (2014). Supported employment: Assessing the evidence. Psychiatric Services, 65(1), 16-23. Martinez, K. (2013). Integrated employment, Employment First, and U.S. federal policy. Journal of Vocational Rehabilitation, 38, 165-168.

National Council on Disability. (2008). Finding the gaps: A comparative analysis of disability laws in the United States to the United Nations Convention on the Rights of Persons with Disabilities. Retrieved from http://www.ncd.gov/publications/2008/May122008

National Council on Disability. (2012). NCD Report on subminimum wage and supported employment.

Retrieved from http://www.ncd.gov/publications/2012/August232012/

National Council on Disability. (2014). National disability policy: A progress report. Retrieved from http://www.ncd.gov/progress_reports/10312014

National Disability Rights Network. (2011). Sheltered and exploited: The failure of the disability service delivery system to provide quality work. Retrieved from http://www.ndrn.org/images/Documents/ Resources/Publications/Reports/Segregated-and-Exploited.pdf

National Disability Rights Network. (2012). Beyond segregated and exploited: Update on the employment of people with disabilities. Retrieved from http://www.ndrn.org/images/Documents/Resources/

Publications/Reports/Beyond_Segregated_and_Exploited.pdf

Oliver, M. (1996). Understanding disability: From theory to practice. Basingstoke: Macmillan.

Olmstead v. LC. ex rel. Zimring, 527 U.S. 581 (1999).

Perez, T. (2015, January 5). Ensuring “opportunity” extends to all. [U.S. Department of Labor Blog post]. Retrieved from http://blog.dol.gov/2015/o1/o5/ensuring-opportunity-extends-to-all/

Rehabilitation Act of 1973, 29 U.S.C. $\$ 701$ et seq.

Rehabilitation Act Amendments of 1986, Pub. L. PL 99-506, codified as amended at 29 U.S.C. $\$ 701$ et seq.

Rehabilitation Act Amendments of 1992, Pub. L. 102-569, codified as amended at 29 U.S.C. $\$ 701$ et seq. Reskin, B. F. (2001). Employment discrimination and its remedies. In I. Berg \& A. L. Kalleberg (Eds.), 
Sourcebook of labor markets: Evolving structures and processes (pp. 567-599). New York, NY: Kluwer/ Plenum.

Rinaldi, G. (2014). Gimme shelter: Lane v. Kitzhaber and its impact on integrated employment services for people with disabilities. American University Journal of Gender, Social Policy, and Law, 22(3), 749-779. Retrieved from http://digitalcommons.wcl.american.edu/cgi/viewcontent. cgi? article $=1643 \&$ context $=$ jgspl

Rubin, S. E., \& Roessler, R. T. (2007). Foundations of the vocational rehabilitation process $\left(6^{\text {th }} \mathrm{ed}.\right)$. Austin, TX: PRO-ED.

Schlesinger, L. (2014). The social model's case for inclusion: "Motivating factor" and "but for" standards of proof under the Americans with Disabilities Act and the impact of the social model of disability on employees with disabilities. Cardozo Law Review, 35(5), 2115-2145. Retrieved from http://www. cardozolawreview.com/content/35-5/SCHLESINGER.35.5.pdf

Scotch, R. K. (2000). Models of disability and the Americans with Disabilities Act. Berkeley Journal of Employment and Labor Law, 21(1), 213-222. Retrieved from http://scholarship.law.berkeley.edu/bjell/ $\operatorname{vol} 21 /$ iss $1 / 7$

Shogren, K. A., \& Wehmeyer, M. L. (2014). Using the core concepts framework to understand three generations of inclusive practices. Inclusion, 2(3), 237-247. doi:10.1352/2326-6988-2.3.237

Silverstein, R. (2000). Emerging disability policy framework: A guidepost for analyzing public policy. Iowa Law Review, 85, 1691-1796.

Silverstein, R. (2010). Anatomy of change: The need for effective disability policy change agents.

Archives of Physical Medicine \& Rehabilitation, 91(2), 173-177.

Smyth, F., Shevlin, M., Buchner, T., Biewer, G., Flynn, P., Latimier, C., \& Ferreira, M. A. (2014). Inclusive education in progress: Policy evolution in four European countries. European Journal of Special Needs

Education, 29(4), 433-445. doi: 10.1080/08856257.2014.922797

Stein, M. A., \& Stein, P. J. S. (2007). Beyond disability civil rights. Hastings Law Journal, 58, 1203-1240.

Retrieved from http://scholarship.law.wm.edu/facpubs/263/

Stoddard, S. (2014). 2014 Disability Statistics Annual Report. Durham, NH: University of New

Hampshire. Retrieved from http://www.disabilitycompendium.org/docs/default-source/2014compendium/annual-report.pdf

Taylor, S. J. (1988). Caught in the continuum: A critical analysis of the principle of the least restrictive environment. Journal of the Association for Persons with Severe Handicaps, 13(1), 41-53.

United Nations. (2006). Convention on the rights of persons with disabilities. Geneva, Switzerland:

Author. Retrieved from http://www.un.org/disabilities/convention/conventionfull.shtml

United Nations Enable. (2012). Convention on the rights of persons with disabilities: Latest developments.

Retrieved from http://www.un.org/disabilities/

United States Department of Health and Human Services, Centers for Medicare and Medicaid Services. (2014). Fact sheet: Summary of key provisions of the Home and Community-based Services (HCBS)

Settings Final Rule (CMS 2249-F/2296-F). Retrieved from http://www.medicaid.gov/medicaid-chipprogram-information/by-topics/long-term-services-and-supports/home-and-community-based- 
services/downloads/hcbs-setting-fact-sheet.pdf

United States Department of Justice, Civil Rights Division. (2011). Statement of the Department of Justice on enforcement of the integration mandate of Title II of the Americans with Disabilities Act and Olmstead v. L.C. Retrieved from http://www.ada.gov/olmstead/q\&a_olmstead.htm\#_ftn11

United States Department of Justice, Civil Rights Division. (2014). Department of Justice reaches landmark Americans with Disabilities Act settlement agreement with Rhode Island (Justice News 14-350). Retrieved from http://www.justice.gov/opa/pr/department-justice-reaches-landmark-americansdisabilities-act-settlement-agreement-rhode United States Senate, Health, Education, Labor, and Pensions Committee. (2013). Separate and unequal: States fail to fulfill the community living promise of the Americans with Disabilities Act. Retrieved from http://www.harkin.senate.gov/documents/pdf/OlmsteadReport.pdf Wagner, M., Newman, L., Cameto, R., Levine, P., \& Garza, N. (2006). An Overview of Findings From Wave 2 of the National Longitudinal Transition Study-2 (NLTS2). Menlo Park, CA: SRI International. Retrieved from www.nlts2.org/reports/2006_08/nlts2_report_2006_08_complete.pdf. Wehman, P., \& Moon, S. (1987). Critical values in employment programs for persons with developmental disabilities: A position paper. Journal of Applied Rehabilitation Counseling, 18, 12-16. Wehman, P. (2012). Life beyond the classroom: Transition strategies for young people with disabilities ( $5^{\text {th }}$ ed.). Baltimore, MD: Paul H Brookes.

Wehmeyer, M. L., \& Webb, K. W. (Eds.). (2012). Handbook of adolescent transition education for youth with disabilities. New York, NY: Taylor \& Francis.

West, M. (1996). Promoting self-determination for individuals with severe disabilities in employment services. In D. Sands \& M. Wehmeyer (Eds.), Self-determination across the life span: Independence and choice for people with disabilities (pp. 311-328). Baltimore, MD: Brookes.

Workforce Innovation and Opportunity Act of 2014, Pub. L. 113-128.

World Health Organization. (2001). International classification of functioning, disability, and health $(I C F)$. Geneva, Switzerland: Author.

\section{Biographical note}

Jeanne Novak, Ph.D., is an associate professor of Special Education and coordinator of the graduate teacher preparation program in Secondary Transition at Bowling Green State University, Ohio, USA. Her primary research interests relate to the transition of youth with disabilities from secondary school to integrated employment and postsecondary education. She has authored academic papers and presented internationally in the areas of secondary transition, supported and customized employment for persons with significant disabilities, and personnel preparation in special education and rehabilitation. 